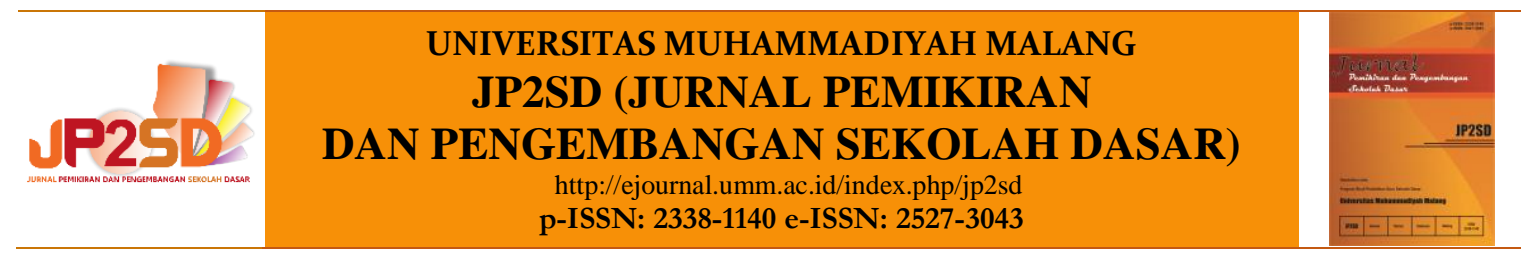

\title{
Pengaruh Direct Reading Thinking Activity Terhadap Keterampilan Membaca Pemahaman di Sekolah Dasar
}

\author{
Trio Ardhian ${ }^{\text {a }}$, Trisniawati $^{\text {b2 }}$ \\ a'Universitas Sarjanawiyata Tamansiswa, Indonesia \\ ${ }^{b}$ Universitas Sarjanawiyata Tamansiswa, Indonesia

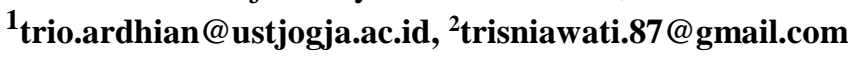 \\ * Penulis Korespondensi
}

\begin{tabular}{ll}
\hline INFORMASI ARTIKEL \\
\hline Riwayat: & \\
Diterima & 23 Februari \\
& 2020 \\
Revisi & 30 Maret \\
& 2020 \\
Dipublikasikan & 26 April \\
& 2020
\end{tabular}

Kata kunci:

Strategi pembelajaran, Directed Reading Thinking Activities (DRTA), keterampilan membaca pemahaman.

\begin{abstract}
ABSTRAK
Penelitian ini bertujuan untuk mengetahui persepsi siswa setelah mengikuti strategi Directed Reading Thinking Activities (DRTA). Metode penelitian yang digunakan adalah metode eksperimen dan teknik analisis data yang digunakan dalam penelitian ini adalah regresi sederhana. Sebelum dilakukan analisis regresi, maka dilakukan uji kualitas data yang meliputi uji validitas dan uji reliabilitas. Selain itu juga dilakukan uji normalitas untuk mengetahui distribusi data penelitian dan juga ui homogenitas. Hasil analisis data menunjukkan bahwa indikator yang digunakan dalam penelitian ini valid, reliable, berdistribusi normal namun tidak homogen. Hasil penelitian menunjukkan bahwa strategi Directed Reading Thinking Activities (DRTA) berpengaruh signifikan terhadap ketrampilan membaca pemahaman siswa yang dibuktikan dengan hasil evaluasi membaca pemahaman yang lebih baik dibandingkan dengan metode konvensional.Kesimpulannya penelitian ini adalah penerapan strategi Directed Reading Thinking Activity (DRTA) sangat efektif dalam meningkatkan keterampilan membaca pemahaman. Keterampilan membaca pemahaman siswa mencapai nilai rata-rata kelas 82,22. Nilai tertinggi adalah 100 sedangkan nilai terendah adalah 70 . Ketuntasan belajar mencapai sebanyak 18 siswa atau sebesar $100 \%$. Pengaruh penerapan strategi Directed Reading Thinking Activity (DRTA) terhadap keterampilan membaca pemahaman pada siswa, mencapai nilai koefisien sebesar 0,988 dan nilai signifikansi sebesar 0,031
\end{abstract}

\section{ABSTRACT}

Keywords:

Learning strategy, Directed

Reading Thinking Activities

This study aims to determine student perceptions after following the Directed Reading Thinking Activities (DRTA) strategy. The research method used is an experimental method and data analysis technique used in this study is a simple regression. Before a 
(DRTA), reading

comprehension skill

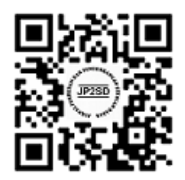

Copyright (C) 2020, Trio Ardhian, Trisniawati

This is an open access article under the CC-BY-SA license

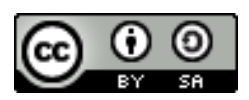

regression analysis is performed, a data quality test is performed which includes a validity test and a reliability test. In addition, normality tests are also conducted to determine the distribution of research data and homogeneity data. The results of data analysis show that the indicators used in this study are valid, reliable, normally distributed but not homogeneous. The results showed that the strategy of Directed Reading Thinking Activities (DRTA) significantly influence students' reading comprehension skills as evidenced by the results of reading comprehension evaluation that are better than conventional methods. The conclusion of this study is that the application of the Directed Reading Thinking Activity (DRTA) strategy is very effective in improve reading comprehension skills. Reading comprehension skills of students reached a grade average of 82.22. The highest score is 100 while the lowest score is 70 . Mastery learning reaches 18 students or $100 \%$. The effect of applying the strategy of Directed Reading Thinking Activity (DRTA) to reading comprehension skills in students, reaching a coefficient value of 0.988 and a significance value of 0.031

How to cite: Trio Ardhian, Trisniawati. (2020). Pengaruh Direct Reading Thinking Activity Terhadap Keterampilan Membaca Pemahaman di Sekolah Dasar. Jurnal Pemikiran dan Pengembangan Sekolah Dasar, Vol 8 No 1, 27-34. doi: https://doi.org/10.22219/jp2sd.v8i1.11364

\section{PENDAHULUAN}

Membaca merupakan aktivitas yang rutin dilakukan oleh seorang siswa dalam pembelajaran di sekolah. Kemampuan membaca juga merupakan modal utama dalam kehidupan setiap pribadi, baik di sekolah maupun di dalam lingkungan masyarakat. Seorang siswa yang mengalami kesulitan belajar cenderung disebabkan kurangnya kemampuan membaca dan minimnya minat untuk membaca. Siswa yang kurang mempunyai keterampilan membaca cenderung tidak dapat memberikan partsipasi aktif dalam aktivitas diskusi.

Standar kompetensi yang mencakup keterampilan membaca diatur dalam Peraturan Menteri Pendidikan Nasional Nomor 22 Tahun 2006 tentang Standar Isi untuk satuan pendidikan dasar dan menengah. Standar kompetensi mata pelajaran Bahasa Indonesia merupakan kualifikasi kemampuan minimal peserta didik yang menggambarkan penguasaan pengetahuan, keterampilan berbahasa, dan sikap positif terhadap bahasa dan sastra Indonesia. Standar kompetensi ini merupakan dasar bagi peserta didik untuk memahami dan merespon situasi lokal, regional, nasional, dan global.

Membaca merupakan suatu keterampilan yang sangat penting untuk dikuasai oleh setiap individu. Tarigan, (2008:7) membaca adalah proses yang dilakukan serta digunakan oleh pembaca untuk memperoleh pesan, yang hendak disampaikan oleh penulis melalui bahasa tulis. Senada dengan pendapat diatas Zare \& Noordin, (2011:188), membaca adalah aktivitas kognitif yang pembaca mengambil bagian dalam percakapan dengan penulis melalui teks. Di sisi lain, strategi membaca dianggap sebagai salah satu fitur psikologi kognitif yang penting untuk pemahaman yang baik

Pendapat serupa juga dikemukakan oleh Grabe, pemahaman membaca secara umum adalah kemampuan memahami informasi dalam sebuah karya teks dan menginterprestasikannya dengan benar dan pemahaman itu sendiri merupakan kemampuan yang kompleks (Biehl, 2013:17) 
Anggreni, Marheini, Dantes, (2013) berpendapat bahwa saat ini siswa dihadapkan pada kesulitan memahami suatu bacaan secara efektif. Rendahnya minat siswa dalam membaca semakin memperburuk kualitas pendidikan, sehingga berdampak pada rendahnya kualitas sumber daya manusia. Oleh karena itu, pandangan terhadap kegiatan membaca harus didasari atas kebutuhan, bukan karena suatu paksaan, sehingga informasi dan pengetahuan yang diharapkan dapat diperoleh. Pendapat tersebut sesuai dengan hasil survey yang dilakukan oleh PIRLS (Progress in International Reading Literacy Study) pada tahun 2011. Hasil survei PIRLS menyatakan bahwa Indonesia mempunyai prestasi membaca di bawah rata-rata negara peserta, yaitu menempati urutan ke-41 dari 45 negara dengan skor 405 (http://litbang.kemdikbud.go.id/index.php/survei-internasional-pirls).

Hasil dari membaca yang diharapkan adalah memperoleh pemahaman. Sebagaimana yang diungkapkan ESRC (Economic and Social Research Council), pemahaman adalah tujuan dari membaca dan mendengarkan. Pemahaman yang baik memungkinkan pembaca atau pendengar untuk memperoleh informasi, pengalaman, dan menyadari keberadaanya untuk berkomunikasi dengan baik, dan untuk mencapai keberhasilan akademisnya (Snowling et al., 2009).

Membaca untuk pemahaman merupakan tujuan utama dari membaca (walaupun terkadang diabaikan ketika siswa diminta untuk membaca teks yang terlalu sulit), meningkatkan kesadaran siswa akan gagasan utama dalam suatu teks dan menelusuri susunan sebuah teks sangat penting untuk pemahaman yang baik (Jack C. Richards, 2003).

Kondisi kurangnya minat membaca di Indonesia juga menjadi perhatian SDN Negaradaha 01 Kecamatan Bumiayu terhadap siswanya. Hasil observasi dan wawancara pada saat pembelajaran Bahasa Indonesia di kelas $\mathrm{V}$ menunjukkan bahwa keterampilan membaca siswa masih rendah. Berikut data tentang keterampilan membaca siswa kelas V SDN Negaradaha 01 Kecamatan Bumiayu:

Tabel 1. Data Siswa Kelas V SDN Negaradaha 01 Bumiayu Kecamatan Bumiayu

\begin{tabular}{lccc}
\hline Keterangan & $\begin{array}{c}\text { Jumlah Murid } \\
\text { Laki-laki }\end{array}$ & $\begin{array}{c}\text { Jumlah } \\
\text { Murid } \\
\text { Perempuan }\end{array}$ & Total \\
\hline $\begin{array}{l}\text { Memiliki } \\
\text { membaca yang tinggi. } \\
\begin{array}{l}\text { Memiliki } \\
\text { membaca yang rendah. }\end{array}\end{array}$ & 6 & 5 & 11 \\
\hline Jumlah & 4 & 3 & 7 \\
\hline & Sumber: Data Primer & 8 & 18 \\
\hline
\end{tabular}

Keterampilan siswa yang rendah dalam hal membaca dikarenakan siswa kurang mempunyai minat membaca saat pembelajaran Bahasa Indonesia. Siswa cenderung tidak aktif dan tidak mempunyai kepercayaan diri untuk menyampaikan pendapat dan pertanyaan, sehingga siswa mengalami kesulitan dalam memahami isi bacaan. Adanya kesulitan yang dialami siswa mengakibatkan rendahnya kemampuan siswa dalam membuat kesimpulan isi bacaan. Cara mengajar guru yang konvensional dengan hanya mengandalkan buku LKS serta kurangnya variasi strategi dan media pembelajaran yang digunakan juga menjadi salah satu penyebab rendahnya keterampilan membaca siswa.

Dalam pembelajaran Bahasa Indonesia terdapat beberapa strategi yang dapat mempengaruhi berhasil atau tidaknya hasil belajar siswa dalam pembelajaran membaca. Menurut Rahim (2018: 47) pemilihan strategi berkaitan erat dengan faktor-faktor yang 
terlibat dalam pemahaman, yaitu membaca teks dan konteks. Dalam strategi pembelajaran Bahasa Indonesia terdapat strategi membaca Direct Reading Thinking Activity (DRTA) yang diharapkan mampu menjembatani permasalahan dalam proses belajar membaca. Pembaca harus mampu menguasai dan memahami bacaan yang dibacanya. Dalam hal ini, unsur yang harus ada dalam setiap kegiatan membaca adalah pemahaman (Martin-Beltrán et al., 2019).

Strategi Direct Reading Thinking Activity (DRTA) ini merupakan penyempurnaan strategi sebelumnya yaitu, Direct Reading Activity (DRA). Melalui strategi Direct Reading Thinking Activity (DRTA) ini, diharapkan tidak hanya mampu mendorong minat baca siswa melainkan siswa dituntut untuk memberikan prediksi dari sebuah cerita dan mengambil kesimpulan dari cerita yang diberikan oleh guru. Menurut Stauffer yang disitir oleh Rahim (2018: 47) menjelaskan bahwa guru bisa memotivasi usaha dan konsentrasi siswa dengan melibatkan mereka secara intelektual serta mendorong mereka merumuskan pertanyaan dan hipotesis, memproses informasi, dan mengevaluasi solusi sementara.

\section{METODE}

Metode penelitian yang digunakan dalam penelitian ini adalah metode eksperimen. Metode eksperimen merupakan bagian dari metode kuantitatif yang mempunyai ciri khas, yaitu adanya kelompok kontrol (Sugiyono, 2010: 107). Metode eksperimen adalah penelitian yang sengaja membangkitkan timbulnya suatu kejadian atau keadaan, kemudian diteliti bagaimana akibatnya. Dengan kata lain, eksperimen adalah suatu cara untuk mencari hubungan sebab-akibat (hubungan klausal) antara dua faktor yang sengaja ditimbulkan oleh peneliti dengan mengeliminasi, mengurangi, atau menyisihkan faktor-faktor lain yang mengganggu. Eksperimen selalu dilakukan dengan maksud untuk melihat akibat suatu perlakuan (Arikunto, 2010: 9)

Penelitian ini menggunakan metode eksperimen untuk melihat atau mengkaji pengaruh strategi Directed Reading Thinking Activities (DRTA) terhadap kemampuan membaca pemahaman siswa kelas V SD Negeri Negaradaha 01 Kecamatan Bumiayu Tahun Pelajaran 2013/2014. Dalam perwujudan penelitian ini, peneliti menggunakan desain Control Group Posttest-Only Design. Desain penelitian ini dapat digambarkan sebagai berikut:

Tabel 2. Desain Penelitian

\begin{tabular}{lll}
\hline Eksperimen & $\mathrm{X}$ & $\mathrm{O} 1$ \\
\hline Kontrol & - & )$_{2}$ \\
\hline
\end{tabular}

Keterangan:

$\mathrm{X}=$ Perlakuan yang dilakukan pada kelas, yaitu dengan strategi Directed Reading Thinking Activities (DRTA).

$\mathrm{O}_{1}=$ Posttest kelompok eksperimen menggunakan strategi Directed Reading Thinking Activities (DRTA) dalam pembelajaran membaca pemahaman.

$\mathrm{O}_{2}=$ Posttest kelompok kontrol tidak menggunakan strategi Directed Reading Thinking Activities (DRTA) dalam pembelajaran membaca pemahaman.

Penelitian ini dilaksanakan untuk membuktikan pengaruh variabel $\mathrm{X}$ terhadap variabel Y, dalam hal ini adalah strategi Directed Reading Thinking Activities (DRTA) terhadap ketrampilan membaca pemahaman. Paradigma penelitiannya adalah: 
Keterangan:

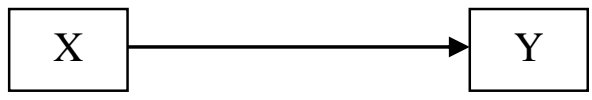

\section{Gambar 1. Paradigma Sederhana}

$\mathrm{X}=$ Strategi Directed Reading Thinking Activities (DRTA).

$\mathrm{Y}=$ Ketrampilan membaca pemahaman.

\section{HASIL DAN PEMBAHASAN}

Hasil penelitian ini diperoleh dari kegiatan observasi aktivitas siswa dan evaluasi terhadap keterampilan membaca pemahaman siswa. Data yang diperoleh dari penelitian ini berupa data kualitatif dan kuantitatif. Data kualitatif berupa data hasil observasi aktivitas siswa, sedangkan data kuantitatif berupa data hasil evaluasi keterampilan membaca pemahaman. Berikut ini adalah paparan hasil penelitian keterampilan membaca pemahaman melalui strategi Directed Reading Thinking Activity (DRTA) pada siswa kelas V SDN Negaradaha 01 Kecamatan Bumiayu. Pada awal pembelajaran metode yang digunakan oleh guru terhadap kelas kontrol menggunakan metode konvensional. Kemudian pada kelas eksperimen guru menggunakan strategi Directed Reading Thinking Activity (DRTA).

\section{Hasil Pengujian Instrumen Penelitian}

a. Uji validitas

Berikut tabel hasil uji validitas mengenai respon siswa terhadap strategi Directed Reading Thinking Activities (DRTA):

Tabel 3. Correlations

\begin{tabular}{lcll}
\hline $\begin{array}{c}\text { Indikator } \\
\text { DRTA }\end{array}$ & $\begin{array}{c}\text { Koefisien } \\
\text { Korelasi }\end{array}$ & $\begin{array}{c}\text { Nilai } \\
\text { Signifikasi }\end{array}$ & Keterangan \\
\hline X1.1 & 0,947 & 0,000 & Valid \\
X1.2 & 0.867 & 0,000 & Valid \\
X1.3 & 0,820 & 0,000 & Valid \\
X1.4 & 0,972 & 0,000 & Valid \\
X1.5 & 0.903 & 0,000 & Valid \\
X1.6 & 0,972 & 0,000 & Valid \\
X1.7 & 0,945 & 0,000 & Valid \\
\hline
\end{tabular}

Hasil uji validitas menunjukkan bahwa indikator yang digunakan untuk mengukur DRTA dalam memprediksi keterampilan membaca pemahaman tersebut valid, yaitu dengan nilai signifikansi sebesar 0,000 $(<5 \%)$.

b. Uji reliabilitas

Berikut tabel hasil uji reliabilitas mengenai respon siswa terhadap strategi Directed Reading Thinking Activities (DRTA):

Tabel 4. Reliability Statistics

\begin{tabular}{cc}
\hline Cronbach's Alpha & N of Items \\
\hline 0,963 & 7 \\
\hline
\end{tabular}


Hasil uji reliabilitas menunjukkan bahwa nilai cronbach alpha sebesar 0,963. Nilai tersebut lebih besar dari 0,70. Oleh karena itu, indikator yang digunakan untuk mengukur Directed Reading Thinking Activities (DRTA) dapat dikatakan reliabel.

Pembahasan hasil penelitian didasarkan pada hasil observasi dan evaluasi pembelajaran membaca pemahaman melalui strategi Directed Reading Thinking Activities (DRTA) pada siswa kelas V SDN Negaradaha 01 Kecamatan Bumiayu. Adapun pembahasan hasil penelitian dijelaskan sebagai berikut:

\section{Hasil Observasi Aktivitas Siswa}

Aktivitas yang dilakukan siswa dalam pembelajaran membaca melalui strategi Directed Reading Thinking Activities (DRTA) ini diamati dengan lembar pengamatan aktivitas siswa yang dibuat berdasarkan teori mengenai aktivitas siswa dan langkahlangkah pembelajaran melalui strategi Directed Reading Thinking Activities (DRTA). Dalam observasi terhadap aktivitas siswa diperoleh indikator keberhasilan dengan perolehan skor sebesar 17,31 dengan kriteria baik.

Indikator pertama yaitu memperhatikan penjelasan guru, skor yang diperoleh 40, dalam indikator tersebut sebagian siswa dapat melaksanakan aktivitas mendengarkan dengan baik serta antusias dalam memperhatikan penjelasan guru. Hal tersebut ditandai dengan adanya sebagian besar siswa yang tenang di dalam kelas, sehingga siswa dapat memahami penjelasan guru.

Indikator kedua membaca judul dan membuat prediksi melalui tanya jawab dengan guru mendapatkan skor 40. Aktivitas siswa yang terjadi pada indikator kedua ini adalah aktivitas visual dan lisan. Aktivitas tersebut dapat terlihat melalui kegiatan siswa pada saat membaca judul dan memberikan tanggapan serta menjawab pertanyaan tentang judul cerita. Kebanyakan siswa telah membaca judul cerita, sehingga dapat memberikan tanggapan dan jawaban terhadap pertanyaan guru yang berkaitan dengan judul cerita yang ditulis di papan tulis.

Indikator ketiga adalah memperhatikan gambar dan membuat prediksi melalui kegiatan diskusi kelompok mendapatkan skor 46 Aktivitas yang terjadi pada indikator ini adalah aktivitas visual, lisan dan mendengarkan. Aktivitas yang dilakukan tersebut dilakukan siswa dengan baik, sehingga banyak siswa yang mampu membuat prediksi yang logis sesuai gambar yang ditampilkan oleh guru.

Indikator keempat yaitu menulis prediksi dari hasil diskusi kelompok mendapat skor 47. Pada indikator keempat, aktivitas yang dilakukan siswa meliputi aktivitas menulis yang ditandai dengan adanya kegiatan siswa menulis hasil diskusi kelompoknya. Pada indikator keempat ini banyak siswa yang dapat melakukan kegiatan menulis prediksi secara individu dan membuat laporan hasil diskusi kelompok.

Indikator kelima yaitu membaca bacaan yang telah dipersiapkan oleh guru mendapat skor 45. Aktivitas yang terjadi pada indikator ini adalah aktivitas visual dengan kegiatan yang berupa membaca cerita. Dalam aktivitas tersebut, kebanyakan siswa kosentrasi saat membaca dan membaca dalam hati.

Indikator keenam menilai ketepatan dan menyesuaikan prediksi mengandung aktivitas visual dan mental yang ditandai dengan kegiatan mencermati gambar dan membandingkan atau menganalisis prediksi cerita dengan cerita yang sebenarnya. Pada indikator ini skor yang diperoleh adalah 50. Dalam aktivitas ini banyak siswa yang mencari ide pokok dari tiap paragraf, serta membandingkannya dengan prediksi siswa dan menyesuaikan dengan prediksi yang sebenarnya. 
Lebih lanjut, pada indikator yang terakhir atau ketujuh yaitu mengerjakan soal evaluasi mendapat skor 44. Aktivitas yang terjadi meliputi aktivitas visual, menulis dan emosional. Pada indikator ini sebagian besar siswa dapat mengerjakan soal evaluasi yang diberikan oleh guru dengan percaya diri, sehingga banyak siswa yang selesai dalam mengerjakan soal.

Hasil evaluasi mencerminkan bahwa pembelajaran membaca pemahaman melalui strategi Directed Reading Thinking Activities (DRTA) dapat meningkatkan keterampilan membaca pemahaman siswa yang terlihat dari meningkatnya hasil evaluasi membaca pemahaman siswa. Pernyataan tersebut sesuai dengan pernyataan Stauffer (dalam Rahim Rahim (2018: 47), bahwa strategi Directed Reading Thinking Activities (DRTA) memfokuskan keterlibatan siswa dengan teks, karena siswa memprediksi dan membuktikannya ketika membaca. Melalui aktivitas yang dilakukan dalam strategi Directed Reading Thinking Activities (DRTA), maka siswa dapat melakukan prediksi suatu cerita, dan membuktikan secara langsung ketika membaca, sehingga siswa dapat memahami isi suatu teks dan dapat meningkatkan kemampuan membaca pemahamannya.

Bariska, (2013) memperkuat penelitian sebelumnya bahwa strategi DRTA dapat meningkatkan keterampilan membaca. Melalui berbagai pengalaman dalam belajar, maka dapat mendukung proses dalam meningkatkan kemampuan siswa dalam membaca pemahaman.

Selain data yang berupa data hasil observasi dan evaluasi, ada juga data pendukung penelitian yang berupa data hasil angket siswa, catatan lapangan, dan dokumentasi terhadap pelaksanaan pembelajaran membaca pemahaman melalui strategi Directed Reading Thinking Activities (DRTA). Respon Siswa Terhadap Pembelajaran Membaca melalui strategi Directed Reading Thinking Activities (DRTA).

\section{SIMPULAN}

Berdasarkan hasil penelitian yang telah dilaksanakan, terdapat beberapa temuan bahwa penerapan strategi Directed Reading Thinking Activity (DRTA) pada siswa kelas V SDN Negaradaha 01 Kecamatan Bumiayu sangat efektif dalam meningkatkan keterampilan membaca pemahaman. Keterampilan membaca pemahaman pada siswa kelas V SDN Negaradaha 01 Kecamatan Bumiayu mencapai nilai rata-rata kelas 82,22. Nilai tertinggi adalah 100 sedangkan nilai terendah adalah 70. Ketuntasan belajar mencapai sebanyak 18 siswa atau sebesar $100 \%$. Pengaruh penerapan strategi Directed Reading Thinking Activity (DRTA) terhadap keterampilan membaca pemahaman pada siswa kelas V SDN Negaradaha 01 Kecamatan Bumiayu memiliki nilai koefisien sebesar 0,988 dan nilai signifikansi sebesar 0,031 .

\section{REFERENSI}

Anggreni, K.Putri; Marheini, AAIN; Dantes, G. R. (2013). Pengaruh Strategi Directed Reading Thinking Activity (DRTA) terhadap Sikap Sosial dan Kemampuan Membaca Pemahaman Bahasa Inggris Siswa Kelas VIII SMP Dharma Wiweka Denpasar. 3(3), 0-11.

Arikunto, S. (2010). Prosedur Penelitian Suatu Pendekatan Praktek. Rineka Cipta.

Bariska, H. F. (2013). Penerapan Strategi Direct Reading Thinking Activity (DRTA) untuk Meningkatkan Keterampilan Membaca Pemahaman Siswa Kelas V. JPGSD, Volume 01, 0-216.

Biehl, P. F. (2013). Teaching and Researching Cultural Heritage. 
https://doi.org/10.1007/978-1-4614-6077-0_6

Jack C. Richards, W. A. R. (2003). The English Teacher as Professional. in Cambridge University Press (Vol. 57, Issue 4, p. 480). Cambridge University Press. https://doi.org/10.2307/812663

Martin-Beltrán, M., Montoya-Ávila, A., García, A. A., Peercy, M. M., \& Silverman, R. (2019). 'Time for Una Pregunta': Understanding Spanish Use and Interlocutor Response among Young English Learners in Cross-age Peer interactions while Reading and Discussing Text. International Journal of Bilingual Education and Bilingualism, 22(1), 17-34. https://doi.org/10.1080/13670050.2018.1515176

Rahim, F. (2018). Pengajaran Membaca di Sekolah Dasar. Bumi Aksara.

Snowling, M., Cain, K., Nation, K., \& Oakhill, J. (2009). Reading Comprehension: Nature, Assessment and Teaching. ESRC Booklet. http://eprints.lancs.ac.uk/50134/

Sugiyono. (2010). Metode Penelitian Pendidikan: Pendekatan Kuantitatif, dan R\&D. Alfabeta.

Tarigan, H. G. (2008). Membaca. Angkasa.

Zare, P., \& Noordin, N. (2011). The Relationship between Language Learning Strategy Use and Reading Comprehension Achievement Among Iranian Undergraduate EFL Learners. World Applied Sciences Journal, 13(8), 1870-1877. 